\section{REM-søvnatferdsforstyrrelse}

\section{REM-søvnatferdsforstyrrelse har ulik presentasjon hos kvinner og menn med Parkinsons sykdom.}

REM-søvnatferdsforstyrrelse karakteriseres av fravær av atoni under REM-søvn. Pasienter kan sparke, slå eller skrike når de sover. Tilstanden er sjelden i befolkningen, men vanligere ved Parkinsons sykdom. Det kan oppstå før eller etter Parkinsons sykdom er diagnostisert. Idiopatisk REM-søvnatferdsforstyrrelse er den største risikofaktoren for utvikling av Parkinsons sykdom, der tilnærmet alle vil få sykdommen. Omtrent $90 \%$ av pasienter med idiopatisk REM-søvnatferdsforstyrrelse er menn.

I mitt doktorgradsarbeid har vi undersøkt 174 pasienter med Parkinsons sykdom for å kartlegge REM-søvnatferdsforstyrrelse og andre ikke-motoriske symptomer. Vi fant en forekomst på $38 \%$, dette økte til $49 \%$ etter tre år. Forekomsten var lik hos begge kjønn, men symptomene var ulike. Menn hadde mer aggressiv atferd når de sov, med slåssing eller skading av seg selv eller partner. REM- søvnatferdsforstyrrelse var assosiert med redusert kognisjon og autonom dysfunksjon. Vi gjorde en genetisk assosiasjonsstudie av 350 pasienter med Parkinsons sykdom og fant en assosiasjon med en variant $i$ genet for alfa-synuklein.

Ulik klinisk presentasjon av REM-søvnatferdsforstyrrelse er en sannsynlig forklaring på den rapporterte kjønnsforskjellen av den idiopatiske formen. Det er viktig å fange opp kvinner med idiopatisk REM-søvnatferdsforstyrrelse for å gi tidlig nevroprotektiv behandling. Resultatene våre støtter også hypotesen om at REM-søvnatferdsforstyrrelse er en markør for en undergruppe av Parkinsons sykdom med mer uttalte kognitive og autonome symptomer.

Kari Anne Bjørnarå

kari.anne.bjornara@vestreviken.no

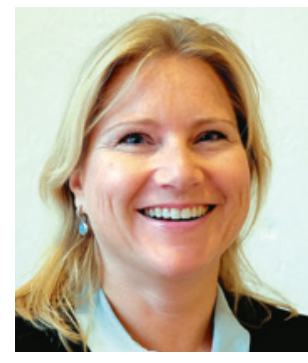

Kari Anne Bjørnarå. Foto: Vestre Viken

Disputas

Kari Anne Bjørnarå disputerte for ph.d.-graden ved Universitetet i Oslo 13.11. 2015. Tittelen på avhandlingen er Clinical and genetic aspects of REM sleep behavior disorder in Parkinson's disease.

\title{
Hyperemesis gravidarum - langtidskonsekvenser for mor og barn
}

\section{Hyperemesis gravidarum kan øke risikoen for kreft hos mor senere i livet.}

Uttalt svangerskapskvalme er den vanligste årsaken til innleggelse i sykehus i første trimester. Vi vet gjennom såkalte sultstudier at ernæring i mors liv er viktig for sykdomsmønstre i voksen alder for barnet. Vi vet også at mors helse på lang sikt kan påvirkes av svangerskapskomplikasjoner.

I mitt doktorgradsarbeid har vi brukt data fra de skandinaviske kreft- og fødselsregistrene for å undersøke kreftrisikoen blant mødre med hyperemesis gravidarum og deres barn. I tillegg har vi undersøkt, blant mer enn 2,2 millioner norske gravide, risikoen for uheldige fødselsutfall, som for tidlig fødsel, lav fødselsvekt og dødelighet hos kvinner med hyperemesis gravidarum.

Vi fant at barn født av kvinner med uttalt svangerskapskvalme fødes til omtrent samme tid og med samme vekt som andre barn. Dette kan indikere at vi er flinke til å diagnostisere og behandle disse pasientene. Barna ser heller ikke ut til å ha økt risiko for kreft før 21-årsalderen. Mødre som har hatt sykdommen, hadde en økt risiko for thyreoideakreft, særlig de med mer enn ett svangerskap med hyperemesis gravidarum. Dette kan passe med den hormonelle profilen forbundet med hyperemesis gravidarum.

Funnene avkrefter tidligere antagelser om at disse barna blir født små og for tidlig. Videre ser det ut som at hyperemesis gravidarum kan ha betydning langt utover svangerskapet for mors helse. Hvilke biologiske mekanismer som ligger bak, blir et viktig tema for fremtidig forskning.

\section{Kathrine F. Vandraas}

kathvandraas@gmail.com

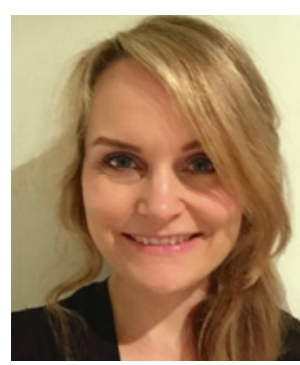

Kathrine F. Vandraas. Foto: Silje Os Skjelsvik

\section{Disputas}

Kathrine F. Vandraas disputerte for ph.d.graden ved Universitet i Oslo 10.11. 2015. Tittelen på avhandlingen er Hyperemesis gravidarum; Exploring potential consequences for mothers and their offspring. 